\title{
Competition between American mink Mustela vison and otter Lutra lutra during winter
}

\author{
Félix BUENO
}

\begin{abstract}
Bueno F. 1996. Competition between American mink Mustela vison and otter Lutra lutra during winter. Acta Theriologica 41: 149-154.

The diet of American mink Mustela vison Schreber, 1777 and otter Lutra lutra (Linnaeus, 1758) and their occupation of the various stretches over approximately 70 $\mathrm{km}$ of two Mediterranean rivers in the centre of Spain were studied during January 1995. No spatial segregation is thought to exist between the two species. The otter diet, mainly fish (93\% of excrement) and American red crayfish Procambarus clarkii $(30 \%)$, is no different from that found in other studies. The mink fed mainly on mammals (present in $52 \%$ of the excrements) and arthropods $(27 \%$ ), while fish are much less common (19\%). The diet is statistically different from that found in a river without otters. The latter eats larger fish and rejects small $(<5 \mathrm{~cm})$ examples, in contrast to mink. The coexistence of the two species is discussed. Despite the considerable overlap in diet the two mustelids can coexist due to the otter's superior ability to capture aquatic prey and the American mink's great degree of ecological adaptability.
\end{abstract}

Av. Menéndez Pelayo 53, 28009 Madrid, Spain

Key words: Lutra lutra, Mustela vison, diet, competition, winter

\section{Introduction}

The introduction of the American mink Mustela vison Schreber, 1777 into Europe during the 1920's and the later establishment of wild populations in various countries (Gerell 1971, Dunstone 1993) given rise to considerable debate on the effects of this species on the ecosystems under colonization and, in particular, its influence on native fauna. The possible competition between otter Lutra lutra (Linnaeus, 1758) and mink has been studied, among others, by Erlinge (1969, 1972), Jenkins and Harper (1980), Chanin 1981, Wise et al. (1981).

In the Iberian Peninsula, the American mink's range, expansion and current distribution are quite well known (see revision in Ruiz-Olmo et al., in press). There have been several Spanish studies of the diet of mink (Ruiz-Olmo 1987, Vidal and Delibes 1987, Bueno 1994) but none on the relationships with its competitors.

The otter diet mostly comprises fish, with differing amounts throughout the year and maximum values in winter (Callejo et al. 1979, Jenkins et al. 1979, Mason and Macdonald 1986, Adrián and Delibes 1987, Callejo 1988, Ruiz-Olmo et al. 1989). For the American mink, fish form the basic group of prey during winter, 
when they too reach their highest values (Gerell 1967, 1968, Chanin and Linn 1980, Dunstone 1993, Bueno 1994). It can be assumed that winter is the season in which the greatest competition should arise. We have attempted to determine the extent of the overlap in their diets and the mechanisms which allow both species to co-exist.

\section{Study area}

A section of the Tiétar river (Tajo basin, central Spain), was surveyed, approximately $70 \mathrm{~km}$ in length and stretching from the Rosarito reservoir to the town of Sotillo de la Adrada. The Guadyerbas river, a tributary of the Tiétar, was also studied. The area has a true Mediterranean climate (Rivas-Martínez 1975). The Tiétar is a Mediterranean river with a flow dependent on rainfall and a very low summer level. The Guadyerbas river dries up completely from the beginning of summer to well into the autumn. A strecht of the Voltoya river (Duero basin) was also surveyed. This river has mink but no otters, further details can be found in Bueno (1994).

\section{Material and methods}

During the first and last weeks of January 1995, seven surveys were made on the river Tiétar and one on the Guadyerbas river looking for signs (tracks and scats) of both species. At each sample station, $1200 \mathrm{~m}$ of the main river and $600 \mathrm{~m}$ of any subsidiary streams found were examined.

The scats collected were wrapped in individual bags, air-dried, washed in cleaning solution and analyzed after being filtered through a riddle with a $0.1 \mathrm{~mm}$ calibre mesh (Webb 1976, Conroy et al. 1993). Insects measuring less than $5 \mathrm{~mm}$ in length and which appeared in connection with possible predators were considered the latter's prey and excluded from the results.

In each scat where fish remains appeared, the length of up to 10 caudal vertebrae were measured (those presenting a well-defined haemal arch) if they were of approximately equal size. If there were vertebrae of various sizes present so as to justify the supposition that they belonged to different preys, up to 10 of each kind were measured. The arithmetical average of the measurements was calculated and the size of each fish was estimated using the method proposed by Wise (1980) with the modifications adopted by Ruiz-Olmo (1995), by means of the following linear function relationship:

$$
y=a x+b
$$

where $y$ is the total length of the fish and $x$ the length of its vertebrae. Values of $a=2.775$ and $b=6.029$, as found by Ruiz-Olmo (1995) in Chondrostoma toxostoma, for all examples of the Cyprinidae.

The fishes were classified into five size ranges $(<5 \mathrm{~cm}, 5-10 \mathrm{~cm}, 10-15 \mathrm{~cm}, 15-20 \mathrm{~cm}$, and $>20$ $\mathrm{cm}$ ) which have been considered sufficient for the purposes of the present study. For comparison, the sizes of 39 fish found in mink scats in January 1995 from the Voltoya river were also estimated.

The results are presented as relative frequency $(\mathrm{RF})$, defined as the percentage of each category of prey over the total number of prey captured, and as percentage frequency (PF), defined as the percentage of the number of scats in which each category of prey appeared.

\section{Results}

In all locations, signs of both species were found, except in the Guadyerbas river where only otter signs were found. Four tributary streams were followed, with signs of American mink being found in two of them (in both cases within the 
Table 1. Relative frequency (RF) and percentage frequency (PF) of prey in the diets of otter and American mink.

\begin{tabular}{lccccc}
\hline & \multicolumn{2}{c}{ Lutra lutra } & & \multicolumn{2}{c}{ Mustela vison } \\
\cline { 2 - 3 } \cline { 5 - 6 } & $\mathrm{RF}$ & $\mathrm{PF}$ & & $\mathrm{RF}$ & $\mathrm{PF}$ \\
\hline Crayfish & 15.74 & 30.43 & & 23.38 & 26.98 \\
Fish & 81.48 & 93.48 & & 19.48 & 19.05 \\
Amphibians & 1.85 & 4.35 & & 3.90 & 4.76 \\
Birds & - & - & & 2.60 & 3.17 \\
Mammals & 0.93 & 2.17 & & 50.65 & 52.38 \\
Number of prey & 108 & & & 77 & \\
Number of faeces & 46 & & & 63 & \\
\hline
\end{tabular}

first 50 metres) and none of the otter. The number of scats from each species in each location is statistically related (Spearman rank correlation, $r_{\mathrm{S}}=0.88$, $p<0.01$ ).

Forty-six otter spraints and sixty-three mink scats were analyzed (Table 1). For otters, fish represented the main resource (present in $93 \%$ of scats), with American red crayfish Procambarus clarkii being next in importance. The diet of the mink was much more varied: mammals were predominant (more than half of the prey and the presences in scats), mainly rabbits Oryctolagus cuniculus. Crayfish were the second group in importance and fish represent a much smaller contribution. The mink's diet is considerably different to that found by Bueno (1994) in a river without otters $\left(\chi^{2}=89.79, \mathrm{df}=4, p<0.001\right)$ basically due to the very different contribution of fish to the total. Of the prey identified in the mink in the river Tiétar, $53.33 \%$ were terrestrial as opposed to only $17.55 \%$ in the river Voltoya, while $98.13 \%$ of the otters' prey were aquatic.

Figure 1 shows the estimated sizes of the fish eaten by otter and mink in the river Tiétar and by the mink in the river Voltoya. Statistically significant differences have been found between the two species in the river Tiétar $\left(\chi^{2}=18.22\right.$,

Fig. 1. Estimated length of the fish captured by Lutra lutra in river Tiétar (black bars), Mustela vison in river Tiétar (open bars) and $M$. vison in river Voltoya (gray bars).

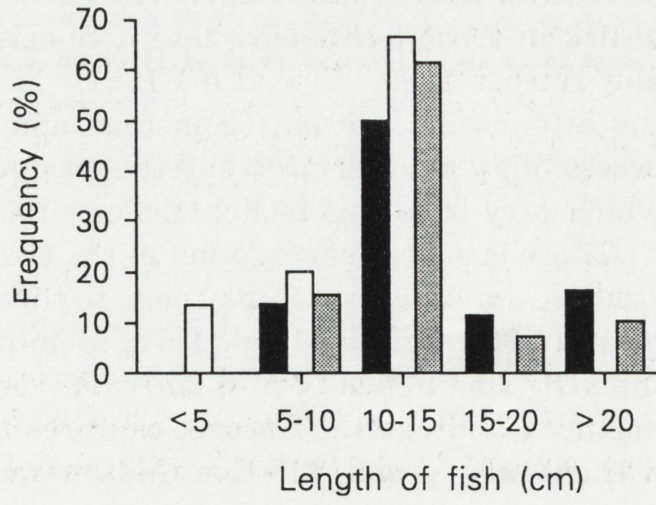


$\mathrm{df}=4, p<0.001$ ); both species are mostly predators of medium-sized fish, but the otter captures more large fish $(>15 \mathrm{~cm})$ and rejects smaller ones $(<5 \mathrm{~cm})$. In mink the trend is the opposite.

There are no statistically significant differences between the sizes of the fish caught by the otter in the river Tiétar and those of the mink in the river Voltoya $\left(\chi^{2}=2.33, \mathrm{df}=3, p>0.3\right)$.

\section{Discussion}

The otter and mink occupy the same stretches of the river Tiétar as signs of both of them were found in all locations. Erlinge (1972) showed a case of spatial segregation between otter and mink, by means of number of scats of each species on different freshwater habitats, with other indirect evidences reinforcing the idea that there was a certain segregation in those areas during the hardest part of the winter, when access to the prey became difficult due to the presence of ice and snow. But, in the present study, conclussions must be made carefully, taking into account the restrictions pointed out by Kruuk et al. (1986) and Kruuk and Conroy (1987), specially the length of shore surveyed, the seasonal variation in sprainting and the fact that otters sometimes defecate in water; both authors concludes that there's no a direct correlation between marking intensity and habitat use. Melquist et al. (1981) found that American mink and North American river otter Lutra canadensis simultaneously occupied the same stretches of a very productive river. The authors did not consider food to be a limiting factor. The river Tiétar seems to be similar with sufficient food resources in terms of fish (Cyprinidae) and alternative prey (crayfish, rabbits, rodents) and a mild climate.

The otter diet is similar to that reported in the literature (see reviews by Mason and Macdonald 1986 and by Ruiz-Olmo 1995) with the exception of the proportion of American crayfish, the importance in Spain of which has been highlighted previously (Delibes and Adrián 1987). Mink has been shown to exhibit great ecological adaptability (Dunstone 1993). In the river Tiétar it fed mainly on terrestrial prey, which corresponds to a general pattern of reduced consumption of fish in those locations where it co-exists with the otter (Erlinge 1972, Jenkins and Harper 1980, Wise et al. 1981). There is greater consumption of fish when the otter is not present (Dunstone and Birks 1987, Bueno 1994), although the accessibility of other prey and the productivity of the river itself give rise to diets which vary from this model (Erlinge 1969, Melquist et al. 1981).

There is a clear segregation in the size of the fish consumed. As shown in other studies, the American mink tends to capture small fish, generally less than $15 \mathrm{~cm}$ (Gerell 1968, Erlinge 1969, 1972, Melquist et al. 1981), whereas the otter rejects the very small ones $(<5-6 \mathrm{~cm})$ and, according to various studies undertaken in northern and central Europe, captures the sizes depending on their abundance, without any special selection (Mason and Macdonald 1986). Nonetheless, studies 
carried out in the Iberian Peninsula suggest that some selection does exist (Callejo 1988, Ruiz-Olmo 1995). The mink does capture occasionally larger fish, especially eels Anguilla anguilla (Chanin 1981, Wise et al. 1981). Larger fish were taken on the river Voltoya, where some may has been as carrion.

There is a clear overlap in diet; approximately $70 \%$ of the otter prey and $44 \%$ of the mink prey are shared and, bearing in mind the size of the fish eaten, the overlap affects $64 \%$ of the former's captures and $87 \%$ of the latter's. In such a situation, the otter modifies its eating habits very little and co-existence depends on its greater ability to capture aquatic prey and the great adaptability of the American mink. The mink is capable of occupying the otter's niche in those locations where the otter is absent or of becoming more land-based when the otter is present. As Vidal and Delibes pointed out (1987), these factors have important implications in the American mink's expansion process, and explain the results of Ruiz-Olmo et al. (in press). The verification of the possible interaction with the polecat Mustela putorius is urgent as the mink coincides with this animal in the Tiétar river.

Acknowledgements: I wish to thank Dr J. Ruiz-Olmo, Dr M. Delibes and C. Bravo for their helpful comments on the original draft of this paper. Two anonymous referees made useful suggestions on the manuscript.

\section{References}

Adrián M. I. and Delibes M. 1987. Food habits of the otter (Lutra lutra) in two habitats of the Doñana National Park, SW Spain. Journal of Zoology, London 212: 399-406.

Bueno F. 1994. Alimentación del visón americano (Mustela vison Schreber) en el río Voltoya (Avila, Cuenca del Duero). Doñana, Acta Vertebrata 21: 5-13.

Callejo A. 1988. Le choix des proies par la loutre (Lutra lutra) dans le nord-ouest de l'Espagne, en rapport avec les facteurs de l'environement. Mammalia 52: 11-20.

Callejo A., Guitián J., Bas S., Sánchez J. L. and Castro A. D. E. 1979. Primeros datos sobre la dieta de la nutria, Lutra lutra (L.), en aguas continentales de Galicia. Doñana, Acta Vertebrata 6: 191-202.

Chanin P. R. F. 1981. Diet of the otter (Lutra lutra) in relation to feral mink (Mustela vison) in two areas of south-west England. Acta Theriologica 26: 83-95.

Chanin P. R. F. and Linn I. J. 1980. The diet of the feral mink (Mustela vison) in southwest Britain. Journal of Zoology, London 192: 205-223.

Conroy J. W. H., Watt J., Webb J. B. and Jones A. 1993. A guide to the identification of prey remains in otter spraint. Mammal Society, London: 1-52.

Delibes M. and Adrián M. I. 1987. Effects of crayfish introduction on otter Lutra lutra food in the Doñana National Park, SW Spain. Biological Conservation 42: 153-159.

Dunstone N. 1993. The mink. T. A. D. Poyser, London: 1-232.

Dunstone N. andy Birks J. D. S. 1987. The feeding ecology of mink (Mustela vison) in coastal habitat. Journal of Zoology, London 212: 69-83.

Erlinge S. 1969. Food habits of the otter (Lutra lutra) and the mink (Mustela vison) in a trout water in southern Sweden. Oikos 20: 1-7.

Erlinge S. 1972. Interspecific relations between otter (Lutra lutra) and mink (Mustela vison) in Sweden. Oikos 23: 327-335.

Gerell R. 1967. Food selection in relation to habitat in mink (Mustela vison). Oikos 18: 233-246. 
Gerell R. 1968. Food habits of the mink (Mustela vison) in Sweden. Viltrevy 5: 119-194.

Gerell R. 1971. Dispersal and acclimatization of the mink (Mustela vison Schreber) in North-Western Europe. Actes du $\mathrm{X}^{\mathrm{e}}$ Congrès. Union International des Biologistes du Gibier, Paris: 327-336.

Jenkins D. and Harper R. J. 1980. Ecology of otters in northern Scotland. II. Analysis of otter Lutra lutra and mink Mustela vison faeces from Deeside, N.E. Scotland in 1977-78. Journal of Animal Ecology 49: 737-754.

Jenkins D., Walker J. G. K. and McCowan D. 1979. Analyses of otter (Lutra lutra) faeces from Deeside, N.E. Scotland. Journal of Zoology, London 187: 235-244.

Kruuk H. and Conroy J. W. H. 1987. Surveying otter Lutra lutra populations: a discussion of problems with spraints. Biological Conservation 41: 179-183.

Kruuk H., Conroy J. W. H., Glimmerveen U. and Ouwererk E. J. 1986. The use of spraints to survey populations of otters Lutra lutra. Biological Conservation 35: 187-194.

Mason C. F. and Macdonald S. 1986. Otters. Ecology and conservation. Cambridge University Press, Cambridge: 1-236.

Melquist W. E., Whitman J. S. and Hornocker M. G. 1981. Resource partitioning and coexistence of sympatric mink and river otter populations. [In: Proceedings of Worldwide Furbearer Conference. Vol. I. J. Chapman and D. Pursley, eds). Frostburg, MD, USA: 187-220.

Rivas-Martínez S. 1975. Mapa de vegetación de la provincia de Avila. Anales del Instituto Botánico A. J. Cavanilles 32: 1493-1556.

Ruiz-Olmo J. 1987. El visón americano, Mustela vison Schreber, 1777 (Mammalia, Mustelidae) en Cataluña, N.E. de la Península Ibérica. Doñana, Acta Vertebrata 14: 142-145.

Ruiz-Olmo J. 1995. Estudio bionómico de la nutria (Lutra lutra L., 1758) en aguas continentales de la Península Ibérica. Ph D thesis, Universidad de Barcelona: 1-321.

Ruiz-Olmo J., Jordán G. and Gosálbez J. 1989. Alimentación de la nutria (Lutra lutra L., 1758) en el Nordeste de la Península Ibérica. Doñana, Acta Vertebrata 16: 227-237.

Ruiz-Olmo J., Palazón S., Bueno F., Bravo C., Munilla I. and Moreno R. 1996. Distribution, status and colonization process of the American mink (Mustela vison Schreber, 1777) in Spain. Biological Conservation. (in press)

Vidal T. and Delibes M. 1987. Primeros datos sobre el visón americano (Mustela vison) en el suroeste de Galicia y noroeste de Portugal. Ecología 1: 145-152.

Webb J. B. 1976. Otter spraint analysis. Mammal Society, London: 1-12.

Wise M. H. 1980. The use of fish vertebrae in scats for estimating prey size of otters and mink. Journal of Zoology, London 192: 25-31.

Wise M. H., Linn I. J. and Kennedy C. R. 1981. Comparison of the feeding ecology of the mink (Mustela vison) and the otter (Lutra lutra). Journal of Zoology, London 195: 181-213.

Received 7 August 1995, accepted 8 February 1996. 